\title{
EVALUATION OF CREEP BEHAVIOR OF TI-6AL-4V ALLOY WITH THERMAL BARRIER COATING DEPOSITED BY AIR PLASMA SPRAY
}

\author{
Filipe Estevão de Freitas ' \\ Adriano Gonçalves dos Reis ${ }^{2}$ \\ Danieli Aparecida Pereira Reis ${ }^{1,3}$
}

\begin{abstract}
Titanium alloys have attractive properties for application in aeronautical components submitted to high temperature. Yttria-stabilized zirconia (YSZ) of thermal barrier coating systems (TBC) have become an alternative to increase the operational lifetime of turbine blades. The aim of this work was to evaluate the creep behavior of Ti-6Al-4V with TBC deposited by air plasma spray. Constant load creep tests were conducted in air on equiaxed Ti-6Al-4V (uncoated) and Ti-6Al-4V with TBC and the experimental parameters related to secondary creep were determined. All the coated samples showed a reduction of secondary creep rate values and, thereafter, higher creep resistance, which could be associated with oxidation protection and thermal insulation provided by the coating. Creep rate analysis suggests that the dominant creep mechanisms in all cases is the dislocation climb.
\end{abstract}

Keywords: Ti-6Al-4V; Creep behavior; TBC.

\section{AVALIAÇÃO DO COMPORTAMENTO EM FLUÊNCIA DA LIGA TI-6AL-4V COM RECOBRIMENTO COMO FORMA DE BARREIRA TÉRMICA DEPOSITADO POR ASPERSÃO TÉRMICA}

\section{Resumo}

Ligas de titânio possuem propriedades atrativas para aplicação em componentes aeronáuticos submetidos a altas temperaturas. O revestimento de barreira térmica (TBC) de zircônia estabilizada com ítria (YSZ) tem se tornado uma alternativa para aumentar a vida operacional das palhetas de turbina. O objetivo deste trabalho foi avaliar o comportamento em fluência da liga Ti-6Al-4V com recobrimento TBC depositado por aspersão térmica. Os ensaios foram conduzidos em carga constante e ao ar em amostras de Ti-6Al-4V com estrutura equiaxial com e sem recobrimento TBC e foram determinados os parâmetros experimentais relacionados à fluência secundária. Todas as amostras revestidas mostraram uma redução dos valores da taxa de fluência secundária e, consequentemente, maior resistência à fluência, que pode ser associada à proteção contra oxidação e à barreira térmica fornecida pelo revestimento. A análise da taxa de fluência sugere que o mecanismo de fluência dominante em todos os casos é a escalagem de discordâncias.

Palavras-chave: Ti-6Al-4V; Comportamento em fluência; TBC.

\section{INTRODUCTION}

High temperature applications, such as aeronautical turbines, have been benefited for decades by new materials development, which has allowed an increase of materials operation temperature $[1,2]$. This creep phenomenon is an important industrial problem due to the increasing level of exigency of industries equipment operation conditions, such as power generation plants, chemical installations and aerospace industries $[3,4]$.

Ti-6Al-4V alloy has been widely used in aeronautical and aerospace industries, particularly for applications requiring high temperature resistance, because its very attractive properties, such as high strength-to-weight

IInstituto de Ciência e Tecnologia - ICT, Universidade Federal de São Paulo - UNIFESP, São José dos Campos, SP, Brasil. E-mail: filipe.estevao@gmail.com ${ }^{2}$ Instituto de Ciência e Tecnologia - ICT, Universidade Estadual Paulista Júlio de Mesquita Filho - UNESP, São José dos Campos, SP, Brasil. ${ }^{3}$ Instituto Tecnológico de Aeronáutica - ITA, Departamento de Ciência e Tecnologia Aeroespacial - DCTA, São José dos Campos, Brasil. 
ratio and metallurgical stability [5-9]. A limiting factor for titanium alloys is the oxygen absorption and consequent oxide formation when exposed to temperatures above $500^{\circ} \mathrm{C}$, reducing its resistance at high temperatures [10].

Thermal Barrier Coatings (TBC) provide oxidation resistance for substrate alloys, reducing the temperature under heat flow conditions and are suitable for use in titanium alloys for long periods at high temperatures [I I, I2]. The TBC system consists of a metallic bond coating (BC) on the substrate, generally MCrAlY type ( $\mathrm{M}=\mathrm{Ni}, \mathrm{Co}, \mathrm{Fe}$ or combinations thereof); a thermally grown oxide (TGO) formed on the MCrAlY by a oxygen diffusion process during the exposure at high temperatures, and an yttria-stabilised zirconia (YSZ) top coating (TC), of low thermal conductivity, bonded to the metallic layer [12-14].

Air Plasma Spray (APS) is a technique for coatings deposition where materials in shape of powder, wire or rod are fed into a torch or gun and heated near their melting point. The droplets are projected towards the substrate surface to be coated. Upon impact, they become thin lamellar particles which adhere to the surface, overlap and then solidify [I5].

The lifetime of stationary gas turbine blades has been significantly increased with use of coatings as a way of alloys protection applied in the manufacture of these components [16]. In addition, studies have been carried out in Ti-6Al-4V alloy with several types of coatings and surface treatments with the aim of improving mechanical properties at high temperatures and oxidation resistance [17-20].

The aim of this work was to evaluate the creep behavior of Ti-6Al-4V alloy with thermal barrier coating deposited by air plasma spray. This study is part of an innovative area of evaluation of creep behavior, showing an important issue in the technological scenario due to the need of Ti-6Al-4V alloy improvement properties at high temperatures and aggressive environment.

\section{MATERIALS AND METHODS}

A commercial Ti-6Al-4V alloy with 12.7 mm diameter rod in hot-forged condition was used for creep test samples. The alloy chemical composition of the elements are conform to ASTM B265 specification [2I] and the creep test samples were made according to ASTM EI 39 standard [22].

The creep specimens were prepared by air plasma spray. Firstly, NiCrAlY (Bond Coat Amdry 962) metal layer was applied, forming a layer of $140 \pm 40 \mu \mathrm{m}$ on the substrate. Then, yttria-stabilized zirconia (8\% YSZ - Top Coat Metco 204NS-G) was applied, forming a ceramic layer of $290 \pm 40 \mu \mathrm{m}$ on the metallic layer. This APS process was performed by the equipment: Sulzer Metco 9 M pistol, Sulzer Metco 9MP powder feeder and Praxair PC- 100 gas controller. Figure I shows the specimen with TBC.

Constant load creep tests were conducted on a standard creep machine in air performed according to
ASTM EI 39 standard [22]. Table I shows the creep tests conditions of equiaxed Ti-6Al-4V (uncoated) and Ti-6Al-4V with TBC samples.

\section{RESULTS AND DISCUSSION}

Figure 2 displays representative creep curves of strain (ع) versus time at 500 to $700^{\circ} \mathrm{C}$ at 125 to $319 \mathrm{MPa}$, where $\mathrm{T}$ is the test temperature and $\sigma$ is the applied stress. Typical creep curves are observed in all conditions with most of the creep life dominated by a constant creep rate, that can be associated with a stable dislocation configuration due to recovery and hardening process.

The results from creep tests are summarized in Table 2, where $\dot{\varepsilon}_{s}$ is steady-state creep rate (or secondary creep rate), $t_{p}$ is the primary creep time, $t_{r}$ is the time to rupture and $\varepsilon_{\mathrm{f}}$ is the strain at fracture.

The results of Table 2 show that with the stress rise on temperature at $600{ }^{\circ} \mathrm{C}$, there is an increase in steady-state creep rate, a decrease in the primary creep time and a reduction of the time to rupture. The same was occurred with the temperature on stress at I25 MPa, considering the conditions evaluated in this work.

The creep resistance is determined, mainly, by the steady-state creep rate. Regarding the uncoated samples, the secondary creep rate of TBC Ti-6Al-4V had a reduction of $33 \%$ at $500{ }^{\circ} \mathrm{C}$ condition, approximately $60 \%$ at $600{ }^{\circ} \mathrm{C}$ condition and $80 \%$ at $700{ }^{\circ} \mathrm{C}$ condition. It is observed that at higher working temperature, the greater is the ceramic coating efficiency under the test conditions. In addition, a higher creep resistance of Ti-6Al-4V alloy with TBC can be associated with thermal barrier improvement and oxidation protection provided by the coating.

The power-law creep equation (Equation I) is a relationship to describe creep behavior [23]:

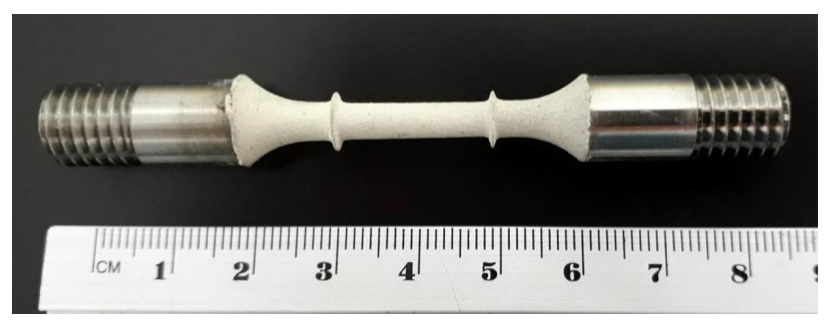

Figure I. Creep test sample with Thermal Barrier Coating.

Table I. Creep tests conditions of equiaxed Ti-6Al-4V with and without TBC

\begin{tabular}{cc}
\hline Temperature $\left({ }^{\circ} \mathbf{C}\right)$ & Stress $(\mathbf{M P a})$ \\
\hline 500 & 125 \\
600 & 125 \\
& 250 \\
& 319 \\
700 & 125 \\
\hline
\end{tabular}

Tecnol. Metal. Mater. Miner., São Paulo, 

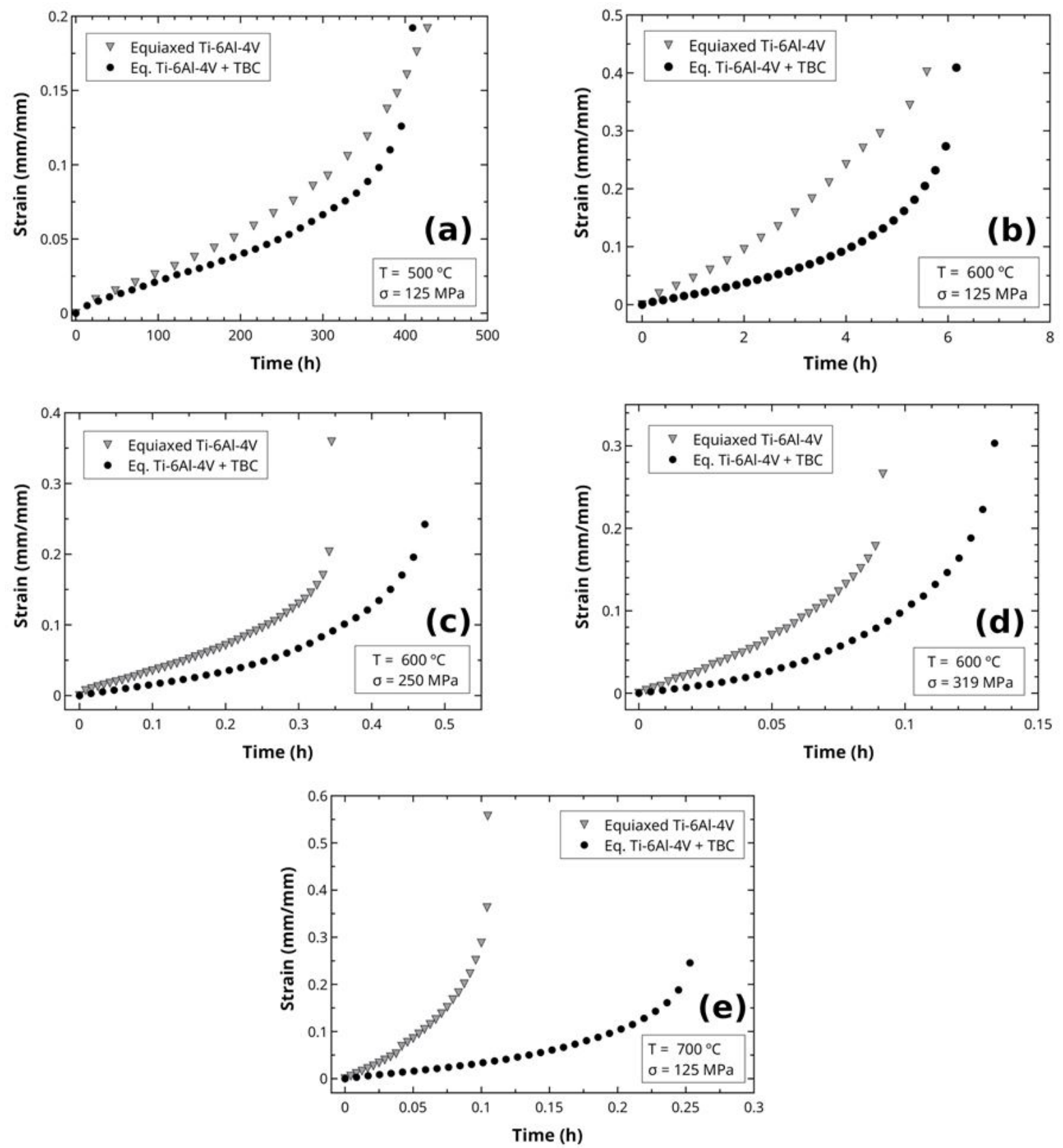

Figure 2. Creep curves of equiaxed Ti-6Al-4V and Ti-6Al-4V with TBC at a) $500{ }^{\circ} \mathrm{C}$ and I $25 \mathrm{MPa}$; b) $600{ }^{\circ} \mathrm{C}$ and I25 MPa; c) $600{ }^{\circ} \mathrm{C}$ and $250 \mathrm{MPa}$; d) $600^{\circ} \mathrm{C}$ and $319 \mathrm{MPa}$; e) $700^{\circ} \mathrm{C}$ and $\mathrm{I} 25 \mathrm{MPa}$.

$$
\dot{\varepsilon}_{s}=\mathrm{B} \sigma^{\mathrm{n}}
$$

where $B$ is structure-dependent constant and $n$ is the creep stress exponent.

Figure 3 shows the steady-state creep rate dependence (at $600{ }^{\circ} \mathrm{C}$ ) to obtain the stress exponent ( $\mathrm{n}$ ) of equiaxed Ti-6Al-4V with and without TBC. The stress exponent found for equiaxed Ti-6Al-4V alloy was 3.59 and for Ti-6Al-4V with TBC was 3.29.

As the creep deformation is a thermally activated process, power-law creep equation can be modified to a temperature dependence, represented by an Arrhenius equation 2 [23]:

$$
\dot{\varepsilon}_{s}=\mathrm{B}_{0} \sigma^{\mathrm{n}} \exp \left(-\mathrm{Q}_{c} / \mathrm{RT}\right)
$$

where $Q_{c}$ is the activation energy for creep, $B_{0}$ is a constant that depends on the microstructure, temperature and applied stress $(\sigma), \mathrm{n}$ is the stress exponent, $\mathrm{R}$ is the universal gas constant and $\mathrm{T}$ absolute temperature. The combination of $n$ and $Q_{c}$ values indicates the main creep mechanism [23]. The dependence of the steady-state creep rate on temperature at I $25 \mathrm{MPa}$ is presented in Figure 4. The activation 
Table 2. Creep data of equiaxed Ti-6Al-4V (uncoated) and Ti-6Al-4V with TBC

\begin{tabular}{ccccccc}
\hline Treatment & $\mathbf{T}\left({ }^{\circ} \mathbf{C}\right)$ & $\sigma(\mathbf{M P a})$ & $\mathbf{t}_{\mathbf{p}}(\mathbf{h})$ & $\dot{\varepsilon}_{\boldsymbol{s}}\left(\mathbf{h}^{-1}\right)$ & $\mathbf{t}_{\mathbf{f}}(\mathbf{h})$ & $\varepsilon_{\mathbf{f}}(\mathbf{m m} / \mathbf{m m})$ \\
\hline Equiaxed Ti-6Al-4V & 500 & 125 & 16.0 & 0.0003 & 427 & 0.1918 \\
& 600 & 125 & 0.67 & 0.0410 & 5.58 & 0.4017 \\
& & 250 & 0.05 & 0.4030 & 0.35 & 0.3590 \\
Ti-6Al-4V with TBC & 700 & 319 & 0.02 & 1.2703 & 0.09 & 0.2658 \\
& 500 & 125 & 0.01 & 1.5084 & 0.11 & 0.5569 \\
& 600 & 125 & 27.3 & 0.0002 & 409 & 0.1922 \\
& & 125 & 0.21 & 0.0187 & 6.16 & 0.4092 \\
& & 250 & 0.03 & 0.1580 & 0.47 & 0.2423 \\
& 700 & 319 & 0.01 & 0.4290 & 0.13 & 0.3032 \\
\hline
\end{tabular}

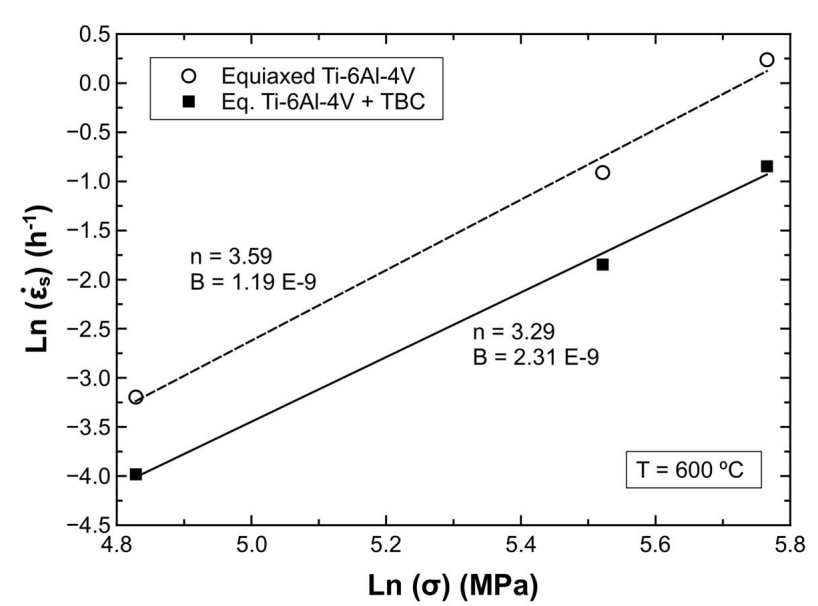

Figure 3. Dependence of steady-state rate on applied stress at $600^{\circ} \mathrm{C}$ for equiaxed Ti-6Al-4V and Ti-6Al-4V with TBC.

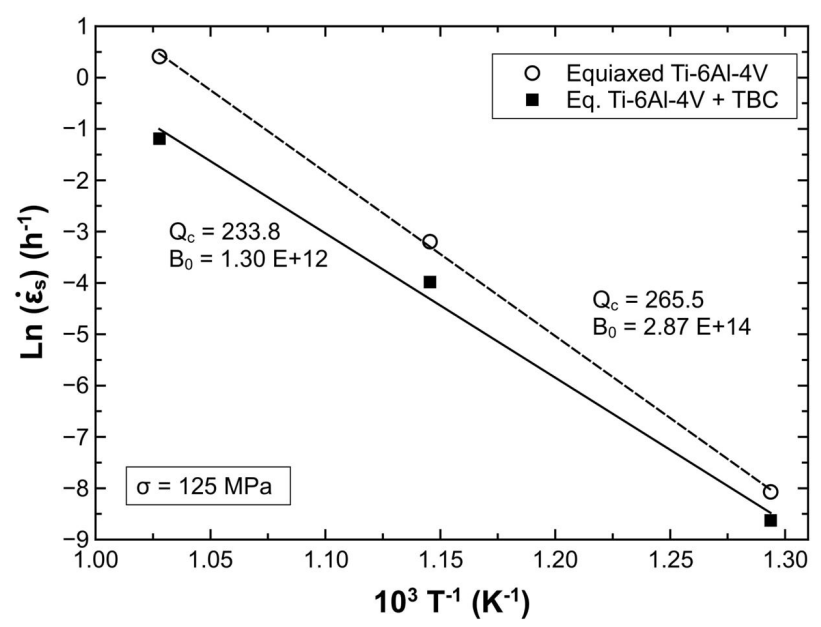

Figure 4. Dependence of steady-state rate on temperature at $125 \mathrm{MPa}$ for equiaxed Ti-6Al-4V and Ti-6Al-4V with TBC.

energy for creep found for equiaxed Ti-6Al-4V and Ti-6Al-4V with TBC was, respectively, $265,5 \mathrm{~kJ} / \mathrm{mol}$ and $233,8 \mathrm{~kJ} / \mathrm{mol}$.

Reis et al. [17] analyzed the creep rates for equiaxed $\mathrm{Ti}-6 \mathrm{Al}-4 \mathrm{~V}$ with and without TBC and suggests that the creep mechanism at 500 and $600{ }^{\circ} \mathrm{C}$ is consistent with the lattice diffusion-controlled dislocation climb process in a-Ti. Warren et al. [24] reported that the stress exponent is $n=3.80$ and the activation energy is $Q c=240.0 \mathrm{~kJ} / \mathrm{mol}$ for Ti-6Al-4V without treatment at $600-680{ }^{\circ} \mathrm{C}$. For the same alloy, Reis et al. [25] found values of $n=4.25$ at the temperature of $600^{\circ} \mathrm{C}$ and $\mathrm{Qc}=218.0 \mathrm{~kJ} / \mathrm{mol}$ for the range of 500 to $700^{\circ} \mathrm{C}$.

According to Evans and Wilshire [23], $\mathrm{n}>3$ and activation energy values close to the material self-diffusion energy indicate the mechanism of low temperature dislocation creep. The self-diffusion activation energy for Ti- $\alpha$ is in the range of 242 to $293 \mathrm{~kJ} / \mathrm{mol}$ [26]. Based on these data, it is concluded that the analysis of stress exponent and activation energy values in conditions presented in this work suggest that the dominant creep mechanism for all cases is primarily controlled by high temperature dislocation climb.

\section{CONCLUSION}

The Ti-6Al-4V with TBC samples presented lower steady-state creep rate and, therefore, higher creep resistance than the uncoated samples. These results reflect the improvement of oxidation resistance and the thermal barrier (lower thermal conductivity) offered to the coated alloy.

For all test conditions, the steady-state creep rate could be described by the Norton law equations, where the values found for the stress exponent were 3.59 and 3.29 and the activation energy for creep were 265.5 and $233.8 \mathrm{~kJ} / \mathrm{mol}$ for the uncoated and Ti-6Al-4V with TBC samples, respectively. Analysis of these values suggests that the dominant creep mechanism is primarily controlled by dislocation climb in all cases.

\section{Acknowledgement}

This work was supported by CAPES foundation, Brazil [grant number 1636393/2016] and by CNPq organization, Brazil [grant number 403070/2016-3]. The authors are grateful to GE Celma (Petrópolis, Brazil) for plasma spray deposition 


\section{REFERENCES}

I Perepezko JH. The hotter the engine, the better. Science. 2009;326(5956): 1068-I069.

2 Shifler D. Future research directions to understanding factors influencing advanced high temperature materials. In: Proceedings of the Ist Department of Defense Corrosion Conference; 2009 August 10- I4; Gaylord National. Washington DC: Department of Defense; 2009. p. 37-34.

3 Meyers MA, Chawla KK. Princípios de metalurgia mecânica. 2nd ed. São Paulo: Edgard Blücher; 1982. Cap. 14, p. 406-420.

4 Eylon D, Fujishiro S, Postans PJ, Froes FH. High-Temperature titanium alloys: A review. Journal of Metals. 2013;36(II):55-62.

5 Leyens C, Peters M. Titanium and titanium alloys. 3rd ed. Weinheim: Wiley; 2003. 499 p.

6 Zhecheva A, Sha W, Malinov S, Long A. Enhancing the microstructure and properties of titanium alloys through nitriding and other surface engineering methods. Surface and Coatings Technology. 2005;200(7):2192-2207.

7 Razavi RS, Gordani GR, Man HC. A review of the corrosion of laser nitrided Ti-6Al-4V. Anti-Corrosion Methods and Materials. 20I I;58(3): I40-I54.

8 Sakai T, Ohashi M, Chiba K, Jonas JJ. Recovery and recrystallization of polycrystalline nickel after hot working. Acta Metallurgica. 1988;36(7): I78I-1790.

9 Lee WS, Lin CF. High-temperature deformation behavior of Ti-6Al-4V alloy evaluated by high strain-rate compression tests. Journal of Materials Processing Technology. 1998;75(I-3): 127-1 36.

10 Gurrappa I, Gogia AK. High performance coatings for titanium alloys to protect against oxidation. Surface and Coatings Technology. 200I;139(2-3):216-22I.

II Almeida DS. Estudo de revestimentos cerâmicos sobre substrato metálico obtido por deposição física de vapores por feixe de elétrons para aplicação como barreira térmica [tese]. São José dos Campos: Instituto Nacional de Pesquisas Espaciais; 2005.

12 Evans HE. Oxidation failure of TBC systems: An assessment of mechanisms. Surface and Coatings Technology. 201 I;206(7):I5I2-I52I.

13 Schulz U, Leyens C, Fritscher K, Peters M, Saruhan-Brings B, Lavigne O, et al. Some recent trends in research and technology of advanced thermal barrier coatings. Aerospace Science and Technology. 2003;7(I):73-80.

I4 Seo D, Ogawa K, Nakao Y, Miura H, Shoji T. Influence of high-temperature creep stresson growth of thermally grown oxide in thermal barrier coatings. Surface and Coatings Technology. 2009;203(14): 1979-1983.

15 Lima CC, Trevisan R. Aspersão térmica. 2nd ed. São Paulo, SP: Artliber; 2007. 152 p.

16 Quadakkers WJ, Shemet V, Sebold D, Anton R, Wessel E, Singheiser L. Oxidation characteristics of a platinized MCrAlY bond coat for TBC systems during cyclic oxidation at $1000^{\circ} \mathrm{C}$. Surface and Coatings Technology. 2005; 199(I):77-82.

17 Reis DAP, Moura Neto C, Silva CRM, Barboza MJR, Piorino Neto F. Effect of coating on the creep behavior of the Ti-6Al-4V alloy. Materials Science and Engineering A. 2008;486(I-2):42 I-426.

18 Oliveira AC, Oliveira RM, Reis DAP, Carreri FC. Effect of nitrogen high temperature plasma based ion implantation on the creep behavior of Ti-6Al-4V alloy. Applied Surface Science. 2014;3 I I:239-244.

19 Reis DAP, Reis AG, Yogi LM, Silva MM, Ueda M, Zepka S. Comparation between Laser Surface Nitriding and Nitrogen Plasma Immersion Ion Implantation (N-PIII) on Creep Behavior of Ti-6Al-4V Alloy. Materials Science Forum. 20। 4;802:462-466.

20 Sugahara T, Martins GV, Montoro FE, Merij Neto A, Massi M, Silva Sobrinho AS, et al. Creep behavior evaluation and characterization of SiC film with $\mathrm{Cr}$ interlayer deposited by HiPIMS in Ti-6Al-4V alloy. Surface and Coatings Technology. 2017;309:410-416.

2I ASTM International. ASTM B265: Standard specification for titanium and titanium alloy strip, sheet, and plate. West Conshohocken: ASTM; 2015.

22 ASTM International. ASTM E 139: Standard test methods for conducting creep, creep-rupture, and stress-rupture tests of metallic materials. West Conshohocken: ASTM; 2011.

23 Evans RW, Wilshire B. Introduction to creep. London: The Institute of Materials; 1993. I I 5 p. 
24 Warren J, Hsiung LM, Wadley HNG. High temperature deformation behavior of physical vapor deposited Ti-6Al-4V. Acta Metallurgica et Materialia. 1995;43(7):2773-2787.

25 Reis AG, Reis DAP, Moura Neto C, Barboza MJR, Oñoro J. Creep behavior and surface characterization of a laser surface nitrided Ti-6Al-4V alloy. Materials Science and Engineering A. 2013;577:48-53.

26 Palehan I, Rosen A. History dependent creep of Ti-6AI-4V alloy. Metal Science. 1978; 12(3): 163-165.

Recebido em: 30 Nov. 2018

Aceito em: 19 Mai. 2019 